\title{
Electronic Curriculum Implementation at North American Dental Schools
}

\author{
William D. Hendricson, M.S., M.A.; Fotinos Panagakos, D.D.S., Ph.D.; \\ Elise Eisenberg, D.D.S.; James McDonald, Ph.D.; Gary Guest, D.D.S.; \\ Pamela Jones, D.D.S.; Lynn Johnson, Ph.D.; Laura Cintron, B.S.
}

Abstract: Electronic curriculum, or E-curriculum, refers to computer-based learning including educational materials available on CD or DVD, online courses, electronic mechanisms to search the literature, email, and various applications of instructional technology including providing laptops to students, multimedia projection systems, and Internet-compatible classrooms. In spite of enthusiasm about the potential for E-curriculum to enhance dental education, there is minimal guidance in the literature to assist schools with implementation. The study objectives were: 1) identify U.S. and Canadian dental schools that have initiated mandatory laptop programs and assess cost, faculty development issues, extent of curricular use, problems, and qualitative perceptions; 2) determine the extent to which twenty-two other E-curriculum resources were available and used at North American dental schools; and 3) identify factors that influenced E-curriculum implementation. A twenty-six item questionnaire, known as the Electronic Curriculum Implementation Survey (ECIS), was mailed to all sixty-six North American dental schools (ten Canadian and fifty-six U.S. schools) during 2002-03 with a response rate of 100 percent. Twenty-five of the twenty-six ECIS questions employed a menu-driven, forced choice format, but respondents could provide amplifying comments. Fifty-three questionnaires were completed by associate deans for academic affairs, three by deans, and ten by instructional technology (IT) managers, IT committee chairs, or directors of dental informatics departments. The survey found that E-curriculum implementation among North American dental schools is following the classic innovation pattern in which a few early adopting institutions proceed rapidly while the majority of potential adopters make modifications slowly. Fourteen U.S. dental schools have established mandatory laptop programs for students. Ten of these laptop programs were created in the past two years; respondents reported numerous growing pains but were generally pleased with their progress. Other E-curriculum capabilities were incorporated into courses more frequently at laptop schools than the fifty-two non-laptop schools including websites, online course evaluations, and instructor use of email to communicate with students. Few dental schools use online courses, and at most schools, few faculty have received training in online instructional techniques. Virtually all North American dental schools have provided substantial instructional technology resources to their faculty, but use of twenty-two components and capabilities of E-curriculum was limited, especially at schools without laptop programs. Various faculty-related issues were reported as implementation barriers including lack of time, skill, and incentive to develop educational software. We conclude that many North American dental schools, especially those with laptop programs, are functioning at the "learn by doing" phase of initial implementation in a four-stage innovation adoption model. E-curriculum planners should pay close attention to implementation problems that occur at this stage where many innovation efforts break down.

Mr. Hendricson is Director, Division of Educational Research and Development, Department of Academic Informatics Services, University of Texas Health Science Center at San Antonio; Dr. Panagakos is Associate Dean, Academic Affairs, University of Medicine and Dentistry of New Jersey; Dr. Eisenberg is Director, Dental Informatics, New York University College of Dentistry; Dr. McDonald is Associate Dean, Curriculum, Indiana University School of Dentistry; Dr. Guest is Director, Predoctoral Clinics, University of Texas Health Science Center at San Antonio School of Dentistry; Dr. Jones is Assistant Dean for Administration, State University of New York at Buffalo School of Dental Medicine; Dr. Johnson is Director of Dental Informatics and Information Technology, University of Michigan School of Dentistry; and Ms. Cintron is Research Associate, Division of Educational Research and Development, University of Texas Health Science Center at San Antonio. Direct correspondence to Mr. William Hendricson, Director, Division of Educational Research and Development, Department of Academic Informatics Services, University of Texas Health Science Center at San Antonio, 7703 Floyd Curl Drive, San Antonio, TX 78229-3900; 210-567-2813 phone; 210-567-2813 fax; hendricson@uthscsa.edu. Reprints will not be available.

The study reported in this paper was supported by the American Dental Education Association's Council of Sections Project Pool. Key words: dental education, instructional technology, online education, faculty development

Submitted for publication 8/2/04; accepted 8/18/04 
E lectronic curriculum, or E-curriculum, refers to computer-based learning, including educational materials available to students by $\mathrm{CD}$ or DVD; online courses and web mechanisms used to search the literature; electronic systems used to enhance academic programs such as email; online testing and course evaluations; and various applications of instructional technology including providing laptops to students, multimedia projection systems, and Internet-compatible, wireless classrooms. A recent study of dental school curriculum innovation by Kassebaum et al. demonstrated there is a high level of interest among dental educators in E-curriculum. ${ }^{1}$ In the Kassebaum et al. study, 86 percent of North American dental schools reported that they had expanded use of instructional technology during the past three years for implementation of core curriculum, and 82 percent of schools desired to increase use of computer-based technology even further during the next three years.

A 2002 literature review performed by the lead author (WH) identified 558 English-language articles published from 1996 to 2002 that addressed some aspect of computer-assisted instruction in the health professions. A second search identified 317 Englishlanguage articles published from 1996 to 2002 that more specifically addressed online (web-based) learning in health professions education or educational materials made available by CD or DVD. The following sources were reviewed to identify this body of literature: MEDLINE, Cochrane Controlled Trials Register, Cochrane Database of Systematic Reviews, Cochrane Database of Abstracts of Reviews of Effectiveness, Excerpta Medica, ERIC (Educational Resources Information Center), CINAHL (Cumulative Index to Nursing \& Allied Health), and LISA (Library and Information Science Abstracts). From both searches (which encompassed the terms "computer-based instruction," "multimedia instruction," and "Internet-based learning"), twenty-nine articles specifically reported some form of computer, multimedia, or web-based instruction in dental education. Among these, only two were literature reviews. ${ }^{2,3}$ The only previous literature review published before 1996 on E-curriculum in dental education that we could identify was by Cohen in 1992. ${ }^{4}$

The majority of the dental education E-curriculum articles fall into four categories: single course project descriptions without outcomes data, surveys of student computer literacy, surveys of student and faculty readiness for computer instruction, and sur- veys designed to elicit student or faculty attitudes about computer learning. None of the dental education E-curriculum articles provided anything more than anecdotal commentary about implementation issues. Thus, in spite of the enthusiasm among dental educators to integrate E-curriculum into their schools' curricula, there is minimal guidance in the literature to assist in their efforts to configure the infrastructure and resources of the institution to implement E-curriculum.

\section{Goal and Rationale: IREC Project}

The IREC Project (Institutional Readiness for Electronic Curriculum) is being implemented by the authors, who comprise the project steering committee, to help answer some of the questions facing dental schools desiring to expand use of E-curriculum. The IREC Project is funded by the American Dental Education Association's Council of Sections Project Pool. The steering committee consists of seven dental school faculty who have leadership roles in Ecurriculum implementation at their schools. Four of the steering committee members have been actively involved in implementation of laptop and software programs associated with Vital Source Technologies, and two others have been involved in implementation of their schools' own laptop initiatives using locally produced curriculum support software.

The long-term goals of the IREC Project are to study E-curriculum infrastructure and implementation issues at North American dental schools, determine the degree to which various E-curriculum resources have been made available to faculty and students, and determine the level of utilization of these resources. The project is being implemented in three phases described in the methods section. Data derived will be used to create an inventory of implementation best practices, which includes an institutional readiness self-assessment instrument that can assist dental schools and other health professions education programs during the potentially rocky startup phase of E-curriculum. The purpose of the inventory is to allow schools to benefit from lessons learned at other institutions and avoid predictable pitfalls when attempting to introduce E-curriculum into the lives of students, teachers, support staff, and administrators. 
Actually implementing a new innovation is the exciting part of the change process: it's personally rewarding and intellectually stimulating for the proponents of the change and often emotionally charged for other individuals who are assigned to implement the "new way of doing things." However, in spite of the excitement of the initial rollout of an innovation, the nature and level of preparation during the three to five preceding years are often more important in determining success or failure than the unique qualities of the innovation itself. ${ }^{5}$ The review of curriculum modification strategies, successes, and failures in health professions education by Bland et al. identified the institutional performance dip (i.e., drop in productivity) that typically accompanies efforts to introduce new educational methods and new organizational relationships in academic institutions. ${ }^{6}$ Research on organizational change and adoption of innovations indicates that reform or modernization efforts often fall apart during the temporary (usually two to three years') performance downswing that occurs while the reform is being incorporated into routine institutional operations and while employees (in this case, faculty) are learning the skills needed to meaningfully utilize new strategies or technologies..$^{7-10}$

Institutions that perform readiness preparation tasks are more likely to be successful than institutions that fail to proactively prepare for implementation. ${ }^{11-14}$ Preparing to implement a change often involves these tasks: 1) conducting an assessment of institutional readiness for the change that will identify the infrastructure modifications needed to support the innovation during the ramp-up period (shortterm) and integration phase (long-term); 2) making necessary infrastructure changes or enhancements; 3 ) redirecting revenue streams to provide adequate and sustainable budgetary support (including anticipating real costs and developing financial sources that will sustain the innovation); 4) providing professional development for faculty and support staff (i.e., training and retooling); 5) providing emotional and social support for staff threatened by change by building grassroots support that includes opportunities for employees (faculty) to participate in planning; 6) creating a realistic plan for phasing in the implementation; and 7) establishing a triage system to promptly cope with predictable implementation problems. ${ }^{9,13,14}$ Many reforms in higher education have been sidetracked or abandoned because of the frustration that builds up among faculty, students, and administrators during bungled attempts to intro- duce a curricular or infrastructure modification without pre-intervention planning. ${ }^{15-18}$

Research on incorporation of new functions and methods into an established organization indicates that institutional assessment and organizational "tickler" systems (such as best practices reminders) are effective strategies for modifying environment and structure in ways that will support the innovation. ${ }^{19-}$ ${ }^{20}$ The IREC Inventory is designed to serve as an infrastructure tickler system for dental school E-curriculum planners. The path to the IREC Inventory involves three phases as described below.

\section{Methods}

The study protocol was approved as exempted research by the Institutional Review Board at the University of Texas Health Science Center at San Antonio (UTHSCSA) on September 12, 2001 (UTHSCSA IRB Protocol \# E-012-017).

\section{Three Phases of the Study}

The IREC study consisted of three phases. Phase one was the previously described literature review on implementation of electronic curriculum in health professions education. This review was conducted from January through March 2002 to guide study design and identify areas of emphasis for phases two and three.

During phase two, which was conducted during the 2002-03 academic year, the Electronic Curriculum Implementation Survey (ECIS) was developed and administered to all North American dental schools to accomplish three objectives: 1) identify the U.S. and Canadian dental schools that have initiated mandatory laptop programs and assess implementation in terms of cost, faculty development issues, extent of curricular use, problems, and qualitative perceptions; 2) determine the extent to which twenty-two other E-curriculum resources were available at U.S. and Canadian dental schools in 2002-03 and determine the degree to which these resources were used to implement curricula; and 3) identify factors that influenced E-curriculum implementation.

A school was designated as having a laptop program if they had one of the following policies: 1) required students to enroll with their own laptop that met hardware and software specifications dictated by the school, 2) required students to purchase or 
lease a laptop from the school at the time of matriculation, or 3) provided a laptop to students without charge. In addition, a laptop program may or may not involve students' mandatory purchase of curriculum support software (for example, the Vital Books DVD created by Vital Source Technologies [VST], which was the principle vendor-produced dental school curriculum resource available at the time of this study). The data derived from the ECIS are presented in the results section of this article.

Based on the ECIS responses provided by each school, sixteen dental schools that have made a major commitment to E-curriculum were identified for in-depth investigation in phase 3 , which was conducted during January-May 2004. The four selection criteria used to identify the major commitment schools were: 1) students are required to purchase/ lease a laptop (with or without associated educational software) and/or 2) more than 33 percent of courses are web-based and use online course evaluations, 3) at least 33 percent of faculty have received training in how to develop online courses with a course management system such as BlackBoard or WebCT, and 4) school has access to an instructional technology unit on campus.

Fourteen of the sixteen schools selected for the phase 3 study operated laptop programs in 2002-03, and the two other schools did not have a laptop program but reported extensive use of online instruction, high levels of faculty training, and access to an instructional technology support unit. For the recently completed phase 3, approximately 1,000 students, 300 course directors, and fifty E-curriculum managers (IT policy makers) at these major commitment schools submitted detailed questionnaires. The student questionnaire consisted of sixty-seven items; the course director questionnaire consisted of seventyfive items; and the E-curriculum manager questionnaire contained twenty-five items. Results of the IREC phase 3 study of the sixteen dental schools with a major commitment to E-curriculum will be reported in a subsequent article.

\section{ECIS (Electronic Curriculum Implementation Survey)}

The ECIS was a twenty-six item questionnaire designed to assess the level of electronic curriculum resources and use at U.S. and Canadian dental schools during the 2002-03 academic year. The IREC Project Steering Committee developed the ECIS in AprilAugust 2002, based on results of the literature re- view and recommendations of the committee members, each of whom had substantial experience and leadership responsibilities for instructional technology in their schools.

Twenty-five of the twenty-six ECIS questions employed a menu-driven, forced-choice format, but respondents were requested to provide amplifying or clarifying comments for most of the questions. The ECIS was originally distributed in a paper-pencil format. Preliminary versions of the ECIS were critiqued by two Ph.D.-level evaluation specialists with expertise in survey development and were completed by ten dental school faculty at the University of Texas Health Science Center at San Antonio to identify unclear directions, questions, or response options. After revisions based on feedback from the survey specialists and faculty, the ECIS was completed by four associate deans and five instructional technology coordinators at medical schools, allied health schools, and nursing schools. These individuals provided additional feedback and recommendations for questionnaire design and wording of questions. Steering committee members also reviewed the ECIS during its development and provided suggestions for improvement.

The final version of the ECIS included questions in two areas:

Laptop Programs. Questions 1-22 focused on the implementation details of mandatory laptop programs, including questions on purchase, lease, or rent arrangements; cost to students; training activities; types, sources, and costs of educational software provided with the laptops; why the school created a laptop program; degree to which the laptop and associated software are integrated into the curriculum; identification of implementation barriers; and qualitative perceptions of value. Schools that did not report existence of a laptop program were asked if they planned to implement such a program in the future.

Other Electronic Curriculum Support. Questions 23 and 24 asked respondents to indicate the level of use of twenty-two capacities and features of E-curriculum that are commonly recommended in the literature for enhancing educational quality or enhancing a school's instructional technology infrastructure. In question 23, respondents were asked to indicate the percentage of courses at their schools that used ten commonly recommended instructional enhancement capabilities such as "course has a website with schedule, lecture outlines, evaluation information"; "course has web-based learning activities such as case simulations, mock exams, or self- 
assessment activities"; or "uses web-based (online) course evaluations." Question 24 asked respondents to indicate if twelve E-curriculum infrastructure support mechanisms existed at their school such as "online course registration and grade assignment"; "students have email accounts paid by the school"; or "students have Internet access in the classroom by accessible jacks or a wireless system." Question 25 asked respondents to indicate the percentage of faculty who had received training in how to use online course management systems such as BlackBoard and WebCT, and question 26 requested recommendations related to implementation of E-curriculum in dental schools.

Using a mailing list obtained from the American Dental Education Association, a package containing the ECIS, a cover letter explaining the project objectives, and an IREC information sheet approved by the UTHSCSA Institutional Review Board was mailed in October 2002 to the associate dean for academic affairs (ADAA) at each U.S. and Canadian dental school. The cover memo requested that the ADAA complete the questionnaire jointly with the school's instructional technology manager, if such an individual existed, or requested that the IT manager complete the survey if the ADAA was not comfortable doing so. Two rounds of follow-up mailouts ultimately produced a 100 percent response by March 2003 from the sixty-six North American dental schools, including the newest schools at the University of Nevada, Las Vegas and the Arizona School of Dentistry \& Oral Health.

Fifty-three questionnaires were completed by ADAAs, three by the schools' dean, and ten by individuals in the following roles: IT manager, faculty who served as chairs of IT committees, and chairs of dental informatics departments. A summary of the results of the ECIS was mailed to all sixty-six North American dental schools in July 2003. The data reported in the following section are purely descriptive given the exploratory nature of the study objectives.

\section{Results}

Responses to the ECIS are described by reporting either raw numbers and/or percentages. The question is presented, followed by a summary of the responses to that item. In some cases, results for interrelated questions are presented together. The number of responses to ECIS items varied based on whether or not the school had a laptop program. Twelve to fourteen schools responded to questions 1-19; fifty-one schools responded to questions 21 and 22 ; and there were sixty-four to sixty-six responses to items 23-25. Many questions asked respondents to consider a list of options in order to answer. In some instances, a truncated version of the original ECIS question is used in the text below for brevity purposes. Results for question 13 (what is the annual cost of laptop and associated software?) are not presented because the responses to question 14 provide essentially the same information. Tables 6 and 8 compare responses from the fourteen laptop schools and the fifty-two schools without a laptop program.

Questions 1 and 2: Are your students required to matriculate in school with their own laptop that meets configuration specifications dictated by the school? - OR - Does your dental school have a program in which students are required to obtain a laptop after they enroll?

Fourteen of the sixty-six dental schools (21 percent) reported that, during the 2002-03 academic year, incoming freshman students were either required to enroll with a laptop that met school-dictated specifications (thirteen schools) or were expected to obtain a laptop after matriculation (one school). Seven of these fourteen laptop schools had contractual agreements with VST to provide curriculum support software.

Questions 3 and 4: Which of the options below best describes how students obtain a laptop? and, If your students lease the laptop, which one of the following options best describes the terms of the lease arrangement?

For questions 3 and 4, respondents were requested to identify how their students acquired laptops from a list of options. ECIS respondents reported a variety of arrangements by which their students obtained laptops. Eight of the fourteen schools with a laptop program reported that their students were required to purchase a laptop from the university at the time of enrollment. At three schools, students could enroll with a laptop they acquired themselves that met school specifications. Two respondents indicated that incoming students leased the laptop from their schools with an option to purchase the laptop with a final payment (i.e., lease with an option to buy). One school reported that they provided laptops to freshmen without charge (i.e., at school expense).

Question 5: If the laptop is leased or purchased, is participation in this laptop program 
required of all students or is participation optional?

Fourteen schools reported that they operated a required laptop program when responding to question 1, but two respondents indicated that participation was optional when answering question 5 . The other twelve schools reported that student participation in the laptop program was mandatory throughout the curriculum.

Question 6: How many years has your school had a laptop program in which students are required to lease or purchase a laptop or to provide their own laptop that complies with certain specifications?

Most of the schools reported limited experience with their laptop program. Ten schools reported one to two years of experience with their laptop program, and four schools had three to five years of experience.

Questions 7 and 8: Does the laptop, whether provided, leased, or purchased, include educational materials (software) to assist the students' learning? And, If educational software is available for students to use with their laptops, how were these materials acquired?

Twelve of the schools provided curriculum software (educational materials) to their students in conjunction with the laptops. Two schools reported that their students received the laptop without any accompanying educational software. Eight of the twelve schools that provided curriculum software reported that their materials consisted of both faculty-produced items and materials purchased from commercial vendors. Three schools provided materials primarily produced by commercial vendors, and one school provided software primarily produced by their faculty.

Question 9: Which of the following statements best describes the process for development of educational software for laptops within your school by your faculty?

At six schools with laptop programs, individual faculty developed educational software for students at their own initiative. Respondents from six other schools indicated that faculty created materials at their own initiative, but they also had a "coordinated program to develop materials in certain key areas of the curriculum." Write-in responses indicated that three of the schools with a coordinated development program relied heavily on the Vital Books software provided by VST.
Question 10: From the list of options below, select the two most typical methods for paying for educational software development within your school.

Respondents could select more than one method for funding software development when answering this question. The top three mechanisms for financing educational software development at the laptop schools were: funds provided by the dean's office, departments absorbed the costs of development, and faculty use their own time and resources to create software for their courses. Other funding mechanisms reported by some respondents included small grants from the parent university, budget support provided by the campus instructional technology unit, and grants obtained from external sources by faculty.

Questions 11 and 12: Do your students pay for the educational software produced locally by your faculty that is provided with their laptops? And, Do your students pay for educational software acquired from commercial vendors that is provided with their laptops?

Although two schools reported in question 7 that they did not provide curriculum software to their students, thirteen respondents answered questions 11 and 12. Eight schools did not require students to pay for software locally produced by the faculty, while five schools indicated that students paid a fee to obtain some or all of the locally produced educational software. For software acquired from commercial vendors, ten of the laptop schools required students to pay some type of fee, which varied considerably among schools based on write-in descriptions of these fees. Three schools charged no student fees for commercially produced educational materials.

Question 14: Which of the following best approximates the total cost (across all four years) for students for your laptop program including the laptop cost (leased or purchased) and software used with the laptop?

As indicated in Table 1, response options for question 14 ranged from "no cost to student" to "more than $\$ 9,000$." Total student costs varied widely from school to school. The most frequently reported fouryear costs were $\$ 2,100$ to $\$ 4,000$ (five schools) and $\$ 6,100$ to $\$ 9,000$ (four schools). One respondent reported that the school picked up the expenses of their laptop program and associated software completely and no costs were passed on to students. Five of the six schools that reported total costs in excess of 
\$6,100 had contracts with VST during the 2002-03 academic year to supply the Vital Books software.

Question 15: Which of the following reasons best describe "why" your school decided to implement a laptop program for your students?

For this question, respondents were asked to identify all items that applied from among fifteen reasons for creating a laptop program. Reasons selected by ten or more of the fourteen laptop schools were: enrich the curriculum (all fourteen schools), enhance student learning (thirteen schools), make learning more efficient (eleven), provide opportunities for faculty innovation (eleven), increase students' information technology skills (eleven), improve student-faculty communication (ten), respond to student expectations for information technology (ten), and provide a more stimulating learning environment (ten).

Question 16: Which of these statements best describe the extent to which faculty have changed their approach to teaching as a result of the laptop program and associated educational software?

For this question, respondents were asked to answer in terms of the "core" teaching faculty who deliver the bulk of the curriculum (i.e., course directors and faculty with heavy teaching loads). The most frequently selected response was "a few of our core teaching faculty have significantly changed their methods" (nine schools). Four respondents selected "most of our core faculty have made tweaks in their methods," and one respondent selected "most of our core teaching faculty have significantly changed their methods." Write-in comments from several respondents indicated that they had not made a systematic effort to assess the impact of the laptop program on teaching or learning methods, and thus their estimation of change was based on personal impressions.

Question 17: To what extent is the laptop program and associated educational software integrated into the core curriculum at your dental school?

To answer this question, respondents were provided four options: "not much at all," "in a few courses," "in some courses," and "extensively throughout the curriculum." Thirteen of the fourteen respondents selected either "in some courses" (seven) or "extensively throughout the curriculum" (six). One school reported "in a few courses," and no respondent selected "not much at all."

Question 18: From your perspective, what have been the most significant implementation problems for the laptop program at your dental school?

For question 18, respondents were asked to identify all problems encountered at their school from among seventeen potential implementation barriers. As indicated in Table 2, three items were identified by at least half of the laptop schools: "faculty lack time to develop educational software" (eleven schools), "faculty lack skills to develop educational software" (eight schools), and "faculty have not modified their courses, teaching, or assessment methods to take advantage of the capabilities of the laptops and software" (seven schools).

Question 19: Up to this point, how would you rate your experience with the laptop program at your dental school?

Five response options were available for this question: "poor," "in general, not positive," "ok, but it needs work," "generally positive," and "excellent." As shown in Table 3, assessment of the laptop experience was skewed toward the positive end of the scale. Ten respondents selected "excellent" or "generally positive," while the other four responses were "it's okay, but needs work." As demonstrated in Table 4, ratings of the laptop program were not associated with student costs. For example, the eight schools that rated their experience as "generally positive" reported student costs ranging from $\$ 2,100$ to more than $\$ 9,000$.

Question 20: If you could make one "lessons learned" recommendation to other dental schools concerning laptop programs, what would it be?

Eleven respondents provided "lessons learned" recommendations related to implementation of a laptop program. Eight of these recommendations emphasized the importance of training the faculty in advance of the laptop program rollout about how to

Table 1. Total cost to students across all curriculum years for the laptop program including equipment and software $\mathrm{N}=14$ U.S. dental schools with a laptop program in the 2002-03 academic year

\begin{tabular}{lcccccc}
$\begin{array}{l}\text { Cost } \\
\text { Category }\end{array}$ & No Cost & $\begin{array}{c}\text { Less than } \\
\$ 2,000\end{array}$ & $\begin{array}{c}\$ 2,100 \\
\text { to } \$ 4,000\end{array}$ & $\begin{array}{c}\$ 4,100 \\
\text { to } \$ 6,000\end{array}$ & $\begin{array}{c}\$ 6,100 \\
\text { to } \$ 9,000\end{array}$ & $\begin{array}{c}\text { More than } \\
\$ 9,000\end{array}$ \\
\hline Number & 1 & 1 & 5 & 1 & 4 & 2
\end{tabular}


Table 2. ECIS respondents' perceptions of the most significant implementation problems for the laptop program at their dental school

$N=14$ U.S. dental schools with a laptop program in the 2002-03 academic year

Implementation Problems Ranked in Order of Reported Frequency

Number of Schools Reporting Problem

Faculty lack time to develop educational software.

11

Faculty lack skills to develop educational software.

8

Faculty have not modified their courses or teaching and assessment methods

to take advantage of the capabilities of the laptops and associated software.

Faculty resistance to something new and different.

7

Faculty have concerns about intellectual property issues related to educational materials they developed for students.

Lack of support staff to help faculty create educational software.

5

Faculty have no financial or career enhancement incentive to develop educational software or modify their courses to take advantage of the students' access to laptops.

Departments lack budget for development of educational software.

1

(1)

Students' laptops, software, and search engines aren't well integrated into the curriculum;

therefore, students have no reason to use the laptops.

Students do not need to use laptops or software to do well in their courses.

Students have negative attitudes toward the laptop program because of the cost.

as providing prompt hardware repair and fixing software glitches).

Questions 21-22: We do not currently have laptop and the educational software into their dayto-day teaching. Several respondents observed that far more attention was devoted to preparing students for the laptop at their schools than was devoted to the faculty. The other three recommendations discussed the need for a reliable support system (such

Table 3. Respondents' ratings of their experience with the laptop program at their dental school

$\mathrm{N}=14$ U.S. dental schools with a laptop program in the 2002-03 academic year

\begin{tabular}{ccccc} 
Poor & $\begin{array}{c}\text { In General, } \\
\text { Not Positive }\end{array}$ & $\begin{array}{c}\text { "OK," But It } \\
\text { Needs Work }\end{array}$ & $\begin{array}{c}\text { Generally } \\
\text { Positive }\end{array}$ & Excellent \\
\hline 0 & 0 & 4 & 8 & 2
\end{tabular}

Table 4. Respondents' ratings of the laptop program at their dental school according to total student cost $\mathrm{N}=14$ U.S. dental schools with a laptop program in the 2002-03 academic year

\section{Total Cost to Student}

\begin{tabular}{|c|c|c|c|c|c|c|}
\hline $\begin{array}{l}\text { Rating } \\
\text { Categories }\end{array}$ & No Cost & $\begin{array}{c}\text { Less than } \\
\$ 2,000\end{array}$ & $\begin{array}{c}\$ 2,100 \\
\text { to } \$ 4,000\end{array}$ & $\begin{array}{c}\$ 4,100 \\
\text { to } \$ 6,000\end{array}$ & $\begin{array}{c}\$ 6,100 \\
\text { to } \$ 9,000\end{array}$ & $\begin{array}{c}\text { More than } \\
\$ 9,000\end{array}$ \\
\hline
\end{tabular}

Poor

In General, Not Positive

"OK," But It Needs Work

Generally Positive

Excellent

$1 \quad 1 \quad \begin{aligned} & 2 \\ & 2 \\ & 1\end{aligned}$
to $\$ 9,000$ $\$ 9,000$ 
program. Respondents answered items 21 and 22 with either "yes" or "no."

Fifty-one of the fifty-two schools that did not have a laptop program in 2002-03 answered questions 21 and 22 about their future plans. Four schools reported that they planned to implement a laptop program in the next two academic years, and thirty-two schools reported that they were evaluating the possibility of implementing a laptop program.

Question 23: Please indicate your best estimate of the percentage of courses in your dental school that currently have the following E-curriculum components.

In question 23, respondents were asked to indicate the percentage of courses at their schools that used ten instructional enhancement capabilities that involve E-curriculum such as websites, online coursework, or electronic course evaluations. These ten E-curriculum components and attributes were included in the survey because they have been frequently advocated in the instructional technology literature as being potentially advantageous to the teaching/learning process. ${ }^{21}$ The response options were: 10 percent or less, 11 percent to 33 percent, 34 percent to 66 percent, and 67 percent to 100 percent. Table 5 presents the responses to this question.

The three E-curriculum components most frequently reported to exist in at least one-third of courses were: "instructor uses email to communicate with students" (existed in at least one-third of courses at 36/66 schools), "web-based course evaluation" (23/66 schools), and "course has website with schedule, lecture outlines, and course information" (23/66 schools). Overall, respondents reported that many of the ten E-curriculum components were not used frequently in the majority of courses at their schools. For example, the following E-curriculum components were reported to exist in less than 10 percent of courses: online courses (fifty-seven schools), online case simulations, mock exams or self-assessment tests (thirty-eight schools), online course manuals (fifty-six schools), Internet chatrooms (fifty-six schools), and electronic testing at websites or computer stations (fifty-three schools). Table 6 compares the use of these ten E-curriculum components between the fourteen laptop schools and the fifty-two schools without laptop programs. Ecurriculum components more likely to be used at laptop schools than at non-laptop schools included course websites, optional resource materials available on the web, online course evaluations, instructors' use of email to communicate with students, and $\mathrm{CD} / \mathrm{DVD}$ resource materials placed in a library or media center.

Question 24: Which of the following schoolwide electronic curriculum support mechanisms currently exist at your dental school?

Question 24 asked respondents to assess implementation of twelve E-curriculum infrastructure support mechanisms, which essentially involve instal-

Table 5. Number of courses in sixty-six North American dental schools in academic year 2002-03 that had ten electronic curriculum components

\begin{tabular}{|c|c|c|c|c|c|}
\hline \multirow[b]{2}{*}{-Curriculum Component } & \multicolumn{5}{|c|}{$\begin{array}{l}\text { Percentage of Courses } \\
\text { with This E-Curriculum Component }\end{array}$} \\
\hline & $\begin{array}{c}10 \\
\text { percent } \\
\text { or less }\end{array}$ & $\begin{array}{c}11-33 \\
\text { percent }\end{array}$ & $\begin{array}{l}34-66 \\
\text { percent }\end{array}$ & $\begin{array}{l}67-100 \\
\text { percent }\end{array}$ & $\begin{array}{c}\text { No } \\
\text { Response }\end{array}$ \\
\hline
\end{tabular}

Course is web-based via WebCT, BlackBoard, or similar course management software.

\section{7}

Course has website with schedule, lecture outlines, or course information.

Course has web-based learning activities such as simulations, mock exams, or self assessment activities.

Course manual is available at website.

Course has optional resource materials available on the web that students can use if they desire.

Course has Internet chatroom.

Course uses electronic testing via website or computer stations.

Course has web-based evaluations.

Instructor uses email to communicate with his or her students.

Resource materials on CD or DVD are available for students in the library or media center.

\begin{tabular}{rrrrr}
57 & 4 & 0 & 3 & 2 \\
24 & 18 & 11 & 12 & 1 \\
38 & 21 & 7 & 0 & 1 \\
56 & 3 & 1 & 2 & 4 \\
22 & 25 & 9 & 8 & 2 \\
56 & 7 & 1 & 1 & 1 \\
53 & 6 & 3 & 1 & 3 \\
37 & 4 & 7 & 16 & 2 \\
16 & 13 & 16 & 20 & 1 \\
32 & 16 & 7 & 9 & 2 \\
\hline
\end{tabular}


Table 6. Comparison of responses from fourteen laptop schools and fifty-two non-laptop schools to ECIS question 23: Indicate your best estimate of the percentage of courses in your dental school that have the following electronic curriculum characteristics. Responses indicate schools that reported that 34-100 percent of their courses had the E-curriculum characteristic identified in the left column.

$\mathrm{N}=66$ North American dental schools in the 2002-03 academic year

E-Curriculum Component

Laptop Schools Non-Laptop Schools

Course is web-based by WebCT or Blackboard or similar course management software.

Course has website with schedule, lecture outlines, or course information.

Course has web-based learning activities such as simulations, mock exams, or self-assessment activities.

Course manual is available at website.

Course has optional resource materials available on the web that students can use if they desire.

Course has Internet chat room.

Course uses electronic testing either via website or at computer stations.

Web-based course evaluation.

Instructor uses email to communicate with students in the course.

Resource materials on CD or DVD are available for students in library or media center.

$\begin{array}{cc}(\mathrm{N}=14) & (\mathrm{N}=52) \\ 1 & 2 \\ \text { (7 percent) } & (4 \text { percent }) \\ 10 & 13 \\ \text { (71 percent) } & (25 \text { percent }) \\ 2 & 5 \\ \text { (14 percent) } & (9.5 \text { percent }) \\ 2 & 1 \\ \text { (14 percent) } & (2 \text { percent }) \\ 6 & 11 \\ \text { (43 percent) } & (21 \text { percent }) \\ 1 & 2 \\ \text { (7 percent) } & (4 \text { percent }) \\ 1 & 3 \\ \text { (7 percent }) & (6 \text { percent }) \\ 11 & 12 \\ \text { (78 percent) } & (23 \text { percent }) \\ 14 & 22 \\ \text { (100 percent) } & (42 \text { percent }) \\ 8 & 8 \\ \text { (57 percent) } & (15 \text { percent }) \\ & \end{array}$

lation of computers, multimedia projection systems, and schoolwide electronic communication systems. Examples of these infrastructure support mechanisms include "online course registration and grade assignment," "students have email accounts paid by the school," and "students have Internet access in the classroom by accessible jacks or a wireless system." The response options were: "yes, we have this"; "it's currently in development"; and "no, don't have this." As demonstrated in Table 7, the respondents reported that their schools had provided a wide array of electronic infrastructure for students and faculty. Only two of the infrastructure items were available at less than half of schools: electronic course registration and grade assignment (thirty-two schools had this in 2002-03, and ten were developing this function), and students have convenient Internet access in classrooms (thirty-one schools had this capacity but sixteen reported it as under development at the time of the survey). At least forty schools reported they already had the other ten infrastructure items.

Table 8 compares the use of these twelve Ecurriculum infrastructure support mechanisms be- tween the fourteen laptop schools and the fifty-two schools without laptop programs. The laptop schools were more likely than the non-laptop schools to have the following electronic curriculum infrastructure: electronic course registration and grade assignment (laptop $=78$ percent; non-laptop $=60$ percent $)$; Internet access for students in classrooms (laptop = 93 percent; non-laptop $=65$ percent); Internet access in clinic for students and faculty (laptop $=100$ percent; non-laptop $=75$ percent); dedicated server for online courses (laptop $=78$ percent; non-laptop $=60$ percent); and staff or faculty who function as a web course manager (laptop $=86$ percent; non-laptop $=69$ percent).

Question 25: What percentage of your faculty have received training in Blackboard or WebCT?

The response options and respondent answers for this question were: less than 10 percent (twentyseven schools), 11 percent to 33 percent (nineteen schools), 34 percent to 66 percent (eleven schools), and 67 percent to 100 percent (nine schools). Eight of the nine respondents that selected 67 to 100 per- 
cent represented schools with a laptop program. Conversely, only one of the laptop schools was among the twenty-seven schools that reported that 10 percent or less of faculty had received training in online teaching methods.

\section{Question 26: Please provide recommenda-} tions related to implementation of E-curriculum in dental schools.

Twenty-four of the survey respondents (36 percent) provided a total of thirty-one write-in recommendations in response to question 26. Seven recommendations stressed the need to establish infrastructure that provides prompt and reliable equipment maintenance and software troubleshooting. Six recommendations emphasized the importance of providing faculty development including strategies to minimize teacher "phobia" about instructional technology. Six respondents recommended creation of a reward system for faculty who desire to create educational software. Five write-in responses discussed the importance of developing an overall E-curriculum vision for the school that was broader than just focusing on laptops, which one respondent described as "just being a piece of hardware" and another described as "only a delivery medium." Four other responses addressed teachers' lack of time to create software, but provided no recommendations.
Three comments identified faculty resistance as a problem, but also provided no recommendations.

\section{Discussion}

A 100 percent response was obtained from the sixty-six North American dental schools, but the data most often represent the perceptions of one individual at each institution - typically, the associate dean for academic affairs. Through comments written on the surveys when they were returned and follow-up communication to clarify information provided, we determined that a number of the respondents did indeed collaborate with other faculty, often the schools' IT manager, when completing the survey. However, in many cases, the responses reflected the viewpoint of a single person within the school, albeit an individual who had responsibility for overall curriculum coordination and thus was in a "position to know" in regard to E-curriculum implementation. Of course, the sole source dilemma is often the situation with survey-based research, but readers are encouraged to consider the data in light of this limitation and also to remember that the data reflect the instructional technology environment at dental schools in the 2002-03 academic year. E-curriculum strategies

Table 7. Number out of sixty-six North American dental schools that had twelve E-curriculum infrastructure mechanisms during academic year 2002-03

\begin{tabular}{|c|c|c|c|}
\hline E-Curriculum Infrastructure Support Mechanism & $\begin{array}{l}\text { Yes, We } \\
\text { Have }\end{array}$ & $\begin{array}{l}\text { Currently in } \\
\text { Development }\end{array}$ & $\begin{array}{l}\text { No, Don't } \\
\text { Have This }\end{array}$ \\
\hline Limited access intranet system for internal communication and curriculum support. & 52 & 6 & 8 \\
\hline Electronic course registration and grade assignment through the school intranet. & 32 & 10 & 22 \\
\hline Students have email accounts paid for by the school. & 65 & 0 & 1 \\
\hline $\begin{array}{l}\text { Faculty have email accounts paid for by the school and Internet access in } \\
\text { their offices. }\end{array}$ & 66 & 0 & 0 \\
\hline $\begin{array}{l}\text { Students have convenient Internet access in classrooms (accessible jacks or } \\
\text { a wireless system). }\end{array}$ & 31 & 16 & 19 \\
\hline Faculty have Internet and school intranet access at classroom podiums. & 54 & 4 & 8 \\
\hline The school or campus has a computer/multimedia laboratory. & 65 & 0 & 1 \\
\hline Students and faculty have convenient Internet access in the clinic. & 38 & 15 & 13 \\
\hline $\begin{array}{l}\text { An information technology unit that helps faculty create web-based courses and } \\
\text { multimedia materials for CD-ROM/DVD. }\end{array}$ & 46 & 4 & 16 \\
\hline $\begin{array}{l}\text { Classrooms are equipped to handle instructional technology such as multimedia } \\
\text { data projectors, laptops, and Internet access. }\end{array}$ & 62 & 4 & 0 \\
\hline Dedicated server for Blackboard and WebCT courses. & 40 & 2 & 23 \\
\hline $\begin{array}{l}\text { A staff or faculty member functions as online course manager (sets up student } \\
\text { accounts, helps faculty and students with problems). }\end{array}$ & 45 & 3 & 18 \\
\hline
\end{tabular}


Table 8. Comparison of responses from fourteen laptop schools and fifty-two non-laptop schools for ECIS question 24: "Which of the following schoolwide curriculum support mechanisms exist at your dental school?" Responses indicate the number and percentage of schools who responded either "yes" or "in development."

E-Curriculum Support Mechanisms

Limited access intranet for internal communication \& curriculum support.

Electronic course registration \& grade assignment through school intranet.

Students have email accounts paid for by the school.

Faculty have email accounts paid for by the school and Internet access in their offices.

Students have convenient Internet access in classrooms via accessible jacks or a wireless system.

Faculty have Internet and school intranet access at classroom podiums.

The school or campus has a computer/multimedia laboratory.

Students and faculty have convenient Internet access in the clinic.

An information technology unit exists to help create web-based courses.

Classrooms are equipped to handle instructional technology such as multimedia data projectors, laptops, and Internet access.

There is a dedicated server for Blackboard and WebCT courses.

Staff or faculty member functions as a web course manager.
Laptop Schools Non-Laptop Schools

\begin{tabular}{|c|c|}
\hline $\begin{array}{c}14 / 14 \\
\text { (100 percent) }\end{array}$ & $\begin{array}{c}44 / 52 \\
\text { (85 percent) }\end{array}$ \\
\hline $\begin{array}{c}11 / 14 \\
\text { (78 percent) }\end{array}$ & $\begin{array}{c}31 / 52 \\
\text { (60 percent) }\end{array}$ \\
\hline $\begin{array}{c}14 / 14 \\
\text { (100 percent) }\end{array}$ & $\begin{array}{c}51 / 52 \\
\text { (98 percent) }\end{array}$ \\
\hline $\begin{array}{c}14 / 14 \\
\text { (100 percent) }\end{array}$ & $\begin{array}{c}52 / 52 \\
\text { (100 percent) }\end{array}$ \\
\hline $\begin{array}{c}13 / 14 \\
\text { (93 percent) }\end{array}$ & $\begin{array}{c}34 / 52 \\
\text { (65 percent) }\end{array}$ \\
\hline $\begin{array}{c}14 / 14 \\
\text { (100 percent) }\end{array}$ & $\begin{array}{c}44 / 52 \\
(85 \text { percent })\end{array}$ \\
\hline $\begin{array}{c}13 / 14 \\
\text { (100 percent) }\end{array}$ & $\begin{array}{c}52 / 52 \\
\text { (100 percent) }\end{array}$ \\
\hline $\begin{array}{c}14 / 14 \\
\text { (100 percent) }\end{array}$ & $\begin{array}{c}38 / 52 \\
\text { (75 percent) }\end{array}$ \\
\hline $\begin{array}{c}11 / 14 \\
\text { (78 percent) }\end{array}$ & $\begin{array}{c}39 / 52 \\
\text { (75 percent) }\end{array}$ \\
\hline $\begin{array}{c}14 / 14 \\
\text { (100 percent) }\end{array}$ & $\begin{array}{c}52 / 52 \\
\text { (100 percent) }\end{array}$ \\
\hline $\begin{array}{c}11 / 14 \\
\text { (78 percent) }\end{array}$ & $\begin{array}{c}31 / 52 \\
\text { (60 percent) }\end{array}$ \\
\hline $\begin{array}{c}12 / 14 \\
\text { (86 percent) }\end{array}$ & $\begin{array}{c}36 / 52 \\
\text { (69 percent) }\end{array}$ \\
\hline
\end{tabular}

have evolved rapidly in health professions education and will continue to do so; thus the lay of the land at a particular school may be different now than it was just twelve to eighteen months ago. We compared the responses from the ten Canadian schools and the fifty-six U.S. schools and identified few differences worth reporting with one exception: as noted previously, none of the Canadian schools reported a laptop program.

\section{Objectives of the Survey}

The objectives of the Electronic Curriculum Implementation Survey (ECIS) were to: 1) identify how many U.S. and Canadian dental schools have initiated mandatory laptop programs and assess implementation in terms of cost, faculty development issues, extent of curricular use, problems, and qualitative perceptions; 2) determine the extent to which various other E-curriculum resources were available and used at dental schools in 2002-03; and 3) identify factors that influenced E-curriculum implemen- tation. The discussion is organized around these three objectives followed by a review of an innovation adoption model to help provide a context for interpreting the ECIS data.

Objective 1: Identify how many U.S. and Canadian dental schools have initiated mandatory laptop programs, and assess implementation in terms of cost, faculty development issues, extent of curricular use, problems, and qualitative perceptions.

Fourteen U.S. schools self-identified that they had a required laptop program during 2002-03. Thirteen schools reported that their students were required to enroll in school with their own laptop that met configuration specifications, and one school reported that their students could purchase or lease a laptop after they enrolled. The cost to students varied widely among the schools. Among the six schools that reported the highest student expense, five were associated with Vital Source Technology at the time of the survey. There did not appear to be a relationship between student cost (which might be considered as 
an indicator of the sophistication of the hardware and software) and the respondents' satisfaction with the program. Several respondents at laptop schools indicated that the program was already substantially integrated into the curriculum even though ten of the schools had only one or two years' experience with this effort. Respondents from ten laptop schools also said that some of their core faculty (e.g., course directors) had already made major changes in teaching methods. These generally positive "curriculum integration" responses from the laptop schools were not consistent with responses to other questions on the ECIS designed to assess use of other E-curriculum resources.

Many of the implementation barriers identified for laptop programs started with the word "faculty." Not surprisingly, lack of faculty time and skill to develop educational software were the primary barriers, along with reluctance to modify courses to take advantage of E-curriculum capabilities. These responses are similar to the results of many other studies that have identified barriers to electronic curriculum implementation. ${ }^{22}$ The majority of the lessons learned recommendations from respondents at the laptop schools emphasized the need for more effective faculty preparation, with emphasis on raising awareness of how to incorporate various E-curriculum capacities into day-to-day teaching. In spite of the numerous implementation barriers that were identified, respondents from the fourteen schools with laptop programs expressed basically positive quality ratings of their experience so far. Only two schools rated the experience as "excellent," but no schools rated the experience as "poor."

In summary, the responses to the ECIS questions that addressed laptop programs suggest that most of the fourteen schools that have embarked on this endeavor are relatively pleased with their progress. Four other schools reported that they were planning to introduce a mandatory laptop program, but we are not aware that any of these schools have actually done so in the time period since the ECIS data was collected.

Objective 2: Determine the extent to which various other electronic curriculum resources were available at U.S. and Canadian dental schools in 2002-03 and determine the degree to which these resources were used to implement the curriculum.

The majority of dental schools have provided their faculty and students with access to numerous instructional technology infrastructure support mechanisms such as those listed in Table 7. For ex- ample, all sixty-six schools reported that their classrooms are equipped to handle contemporary information technology such as data projectors and laptops at classroom podiums. All sixty-six schools reported that they have a computer/multimedia laboratory at their campus. All but one school reported that students have email accounts paid for by the school, and all sixty-six schools reported that their faculty have email accounts paid for by the school. Fiftytwo dental schools have a school intranet for internal communication and curriculum support, and six others are developing this capacity. All but eight schools have Internet and school intranet access at classroom podiums.

For ten E-curriculum components that have been frequently advocated as potential instructional enhancements, such as websites, online coursework, electronic course evaluations, and other items listed in Table 5, the overall level of use was low. For example, fifty-seven of the sixty-six schools reported that 10 percent or less of courses are web-based, which was one of the more surprising findings in this study. Only three of these components - online course evaluations, teacher-student email communication, and course websites - were used with any degree of frequency. However, even these were used in a small percentage of courses at most schools. For example, forty-two schools reported that less than one-third of their courses had websites, and fortyone schools reported that less than one-third of courses used online course evaluations. In contrast, an online survey administered in 2002 by Andrews and Demps found that 31 percent of approximately 400 faculty from an unknown number of dental schools reported that they used web-based learning in their courses. ${ }^{23}$ However, the Andrews and Demps study used different terminology and defined webbased learning more broadly than in this study which may, in part, account for some of the difference in findings. For example, Andrews and Demps included such items as "communication by email," "web resources," and "communication by bulletin board" as components of web-based learning, but these were listed as distinct E-curriculum components in the ECIS.

Not surprisingly, the laptop schools reported generally higher levels of instructional technology infrastructure and more frequent use of certain instructional enhancements provided by E-curriculum than the non-laptop schools. Taken as a whole, the data suggest that the overall impact of these E-curriculum resources, in terms of changing teaching and 
assessment methods, has been limited to this point, especially for the fifty-two non-laptop schools. On the other hand, six of the fourteen laptop schools reported that their laptop initiative and associated educational software had been extensively integrated throughout the curriculum. Thus, E-curriculum implementation among North American dental schools appears to be following the classic organizational change pattern in which a few early adopting institutions proceed rapidly with implementation while the majority of potential adopters make modifications slowly. ${ }^{24}$

Objective 3: Identify factors that influenced Ecurriculum implementation.

One ECIS question addressed this question in relation to laptop programs, and one addressed implementation factors in relation to the overall use of Ecurriculum. Responses from the fourteen laptop schools indicated that the primary implementation factor could be stated in one word: "faculty," in terms of lack of time and skill and apparent reticence to change teaching habits. The lessons learned recommendations stressed the need to enhance training for faculty, and several respondents noted that far more attention had been paid to student training than teacher training. Factors identified by respondents related to E-curriculum in a broad sense were consistent with numerous previous assessments of implementation issues in secondary and university education. ${ }^{25}$ These factors include providing reliable technical support, creating mechanisms to help faculty create software, providing faculty training, and establishing meaningful rewards for course retooling efforts.

\section{Transfer of New Ideas and Operating Routines Within Complex Organizations}

As most dental educators realize, one of the more perilous adventures in academia is the process of introducing a "new way of doing things" into complex organizations, such as dental schools, that have multiple and competing missions and many perspectives among the faculty about the relative importance of these missions and how best to accomplish them. Szulanski described four distinct stages in the transfer of both knowledge and operational strategies (methods or routines) within complex organizations. ${ }^{26}$ Figure 1 is a model based on these transfer concepts and provides a framework for assessing "where we're at" in the process of incorporating Ecurriculum into dental education.

Transfer is the process by which an organization recreates and then strives to maintain a new set of functional routines to accomplish one of its missions. For example, a new functional routine related to the educational mission of a dental school could be providing instruction via online courses rather than classroom lectures. The four stages of the transfer process (which is often referred to as organizational learning $\left.{ }^{27}\right)$ are initiation, initial implementation efforts (often called "first day of use"), ramp-up to satisfactory performance, and integration with other already established routines, in other words, institutionalization.

The initiation stage of the transfer process is usually triggered by one or more of the following: a catalytic event that typically reflects poorly on the institution, ${ }^{28}$ the arrival of a persuasive new leader skilled in orchestrating change, ${ }^{29}$ and/or the availability of new technologies that competitors are adopting or at least perceived to be adopting. ${ }^{30}$ During the initiation phase, the organization, by various means, makes a decision to move ahead with implementing "a new way of doing things" and commences preliminary planning.

The initial implementation of a new routine first involves "learning before doing" that consists of frequent planning meetings among a small group of advocates (often called the inner circle) and conducting experiments with small numbers of subjects in artificial conditions. ${ }^{31}$ These planning sessions and experiments are conducted to try to anticipate what might happen when the new procedure is implemented throughout the organization. Learning before doing is followed by "learning by doing" when the new routine is unveiled for actual use by many other individuals in the organization; this is the proverbial first day of use. Much of the learning by doing stage is consumed with recognition and resolution of unexpected problems that arise during early efforts to implement by individuals who were not centrally involved in planning. The larger group of individuals in an organization who were outside the loop during planning (often called the outer circle) may not share the assumptions, motivation, and skills of the advocacy group, and thus may encounter difficulties in using the new routine and, in an academic environment, may have the option to simply ignore it. Generally, innovation efforts sink or swim during the often-protracted learning by doing phase of initial implementation. ${ }^{26}$ 
Transfer efforts that survive initial implementation evolve into the ramp-up phase, which can span several years as the organization attempts to gradually improve implementation by successive approximation and to produce success stories that justify the effort and motivate individuals on the sidelines (late adopters) to join the effort. The ramp-up phase hopefully will blend seamlessly into the integration phase, when the new routine is no longer perceived as new but is now absorbed into the organizational culture and the psyche of employees as the standard and accepted operational procedure. Depending on the complexity and corresponding threat levels of the innovation, it may take an organization many years to fully complete this four-stage transfer process.
According to Szulanski, the concept of "stickiness," which represents the difficulties that can be experienced during the four phases of re-creating operational routines, is critical to prospectively anticipating pitfalls and retrospectively identifying why an innovation effort failed (i.e., why the effort became stuck). ${ }^{32}$ The three primary sources of stickiness at the initiation stage are related to lack of attentiveness to the operational environment of the organization, known as "slack searching": failure to recognize the need to improve routines and performance, failure to recognize opportunities to make improvements, and failure to identify superior techniques that could be adopted. The four sources of stickiness during initial implementation are: 1 ) inef-

\begin{tabular}{|c|c|c|c|c|}
\hline \multicolumn{5}{|c|}{ Phases During Process } \\
\hline Initiation & Initial Implen & tation Efforts & $\begin{array}{c}\text { Ramp-Up to Satisfactory } \\
\text { Performance }\end{array}$ & Integration \\
\hline $\begin{array}{l}\text { Triggers: } \\
\text { Negative catalytic event. } \\
\text { Persuasive new leader. } \\
\text { Awareness of new } \\
\text { technologies that } \\
\text { competitors may be using. } \\
\text { Institutional commitment: } \\
\text { Decision is made to move } \\
\text { ahead with a new method. } \\
\text { Preliminary planning starts: } \\
\text { Create inner circle group of } \\
\text { advocates and planners. }\end{array}$ & $\begin{array}{l}\text { Learning BEFORE Doing } \\
\text { Inner circle planning } \\
\text { meetings. } \\
\text { Experiments to test new } \\
\text { routine under artificial } \\
\text { conditions. } \\
\text { Decision to move ahead } \\
\text { with formal "roll-out." }\end{array}$ & $\begin{array}{l}\text { Learning } \boldsymbol{B} Y \text { Doing } \\
\text { New routine unveiled } \\
\text { for use by other } \\
\text { members of } \\
\text { organization (outer } \\
\text { circle). } \\
\text { Recognize and resolve } \\
\text { unexpected problems. }\end{array}$ & $\begin{array}{l}\text { Phase May Extend } \\
\text { Over Several Years } \\
\text { Refine and improve } \\
\text { by successive } \\
\text { approximation. } \\
\text { Create successes to } \\
\text { bolster adopters and } \\
\text { motivate non-users } \\
\text { to join the effort. }\end{array}$ & $\begin{array}{l}\text { Institutionalization } \\
\text { New routine is no } \\
\text { longer perceived } \\
\text { to be "new." } \\
\text { Routine blends into } \\
\text { standard operating } \\
\text { procedures of } \\
\text { organization. }\end{array}$ \\
\hline \multicolumn{5}{|c|}{ Sources of Stickiness (Problems, Barriers) } \\
\hline Lack of Attentiveness & Lack of Communication & Training & Slow Response & Lack of Diligence \\
\hline $\begin{array}{l}\text { Failure to recognize need } \\
\text { to improve routines. } \\
\text { Failure to recognize } \\
\text { opportunities to improve. } \\
\text { Failure to identify superior } \\
\text { techniques that could be } \\
\text { adopted. }\end{array}$ & $\begin{array}{l}\text { Poor communication bet } \\
\text { circles. } \\
\text { Outer circle lacks motiva } \\
\text { Outer circle not ready for }\end{array}$ & $\begin{array}{l}\text { en inner and outer } \\
\text { w roles and tasks. } \\
\text { al support, or } \\
\text { r circle. }\end{array}$ & $\begin{array}{l}\text { Failure to quickly } \\
\text { resolve emerging } \\
\text { problems before } \\
\text { they become } \\
\text { complex and } \\
\text { entrenched. } \\
\text { Faulty practice } \\
\text { becomes } \\
\text { institutionalized } \\
\text { and hard to } \\
\text { correct. }\end{array}$ & $\begin{array}{l}\text { Inner circle group } \\
\text { is not persistent } \\
\text { in recognizing } \\
\text { new problems } \\
\text { and minimizing } \\
\text { obstacles. }\end{array}$ \\
\hline
\end{tabular}

Figure 1. Phases during the process of implementing a new operational routine within a complex organization and sources of problems during each phase

Based on: Szulanski G. The process of knowledge transfer: a diachronic analysis of success. Org Behav Human Decision Processes 2000;82(1):9-27. 
fective communication between the inner circle advocates and the other members of the organization who comprise the outer circle; 2) lack of motivation among the outer circle who are expected to "carry the ball" during adoption of the new routine; 3) failure to prepare the outer circle for new tasks and roles, which in the academic environment is essentially a faculty development issue; and 4) failure to provide encouragement, tangible rewards, and emotional support for the outer circle, especially as they struggle with the predictable "first day" implementation pitfalls. There are two sources of stickiness during the phase of ramping-up toward satisfactory performance. ${ }^{33}$ The first sticking point is failure to respond quickly to emerging problems before they get out of hand and thus become too complex to resolve easily. The second area of stickiness during ramp-up, often intertwined with the first sticking point, is institutionalization of faulty practice. If ineffective strategies for using new routines are allowed to linger too long they become increasingly difficult to correct. Stickiness during the final integration stage occurs when the inner circle planning team does not remain diligent in recognizing and then addressing the obstacles and challenges that will inevitably emerge even after several years of implementation. ${ }^{34}$

Reflection on the ECIS data reported in this article suggests that the fourteen dental schools that have created laptop programs are functioning in the "learning by doing" component of initial implementation. The priority in this stage is to detect and promptly resolve unanticipated bumps in the road that arise during the first use efforts. In the academic setting, a schoolwide rollout of an innovation such as a laptop program requires cooperation and skilled performance by many outer circle faculty who were not centrally involved in planning. However, these individuals may or may not be well trained, may or may not perceive the advantages of the laptop in the same way as the inner circle advocates, and may or may not have the same motivation and enthusiasm to "make it work" as the core planning group. The four areas of stickiness associated with learning by doing in initial implementation were all mentioned by ECIS respondents in their lessons learned recommendations. The fifty-two schools that do not have a mandatory laptop program have also provided impressive instructional technology for their faculty, but the instruction-enhancing capacities of these technologies are not widely used, suggesting that the sources of stickiness that arise during initial imple- mentation particularly need to be addressed in these schools.

So what does all this mean? Dental schools planning future roll-outs of E-curriculum should review Figure 1 and make plans to address the areas of stickiness likely to occur throughout the implementation process with a particular focus on providing outer circle faculty with training, rewards, and emotional support during the learning by doing phase.

\section{Conclusions}

The fourteen North American dental schools that have established mandatory laptop programs are functioning as early adopters of E-curriculum. In addition to the laptops and associated software, other E-curriculum capabilities are more likely to be incorporated into courses at the laptop schools than at the non-laptop schools including websites, online course evaluations, and instructors' use of email to communicate course information to students. Many of the laptop programs were in their infancy at the time of the study (less than two years of experience) and respondents reported predictable growing pains, but overall the laptop schools appear to be relatively pleased with their progress. Few dental schools are making extensive use of online courses, and at most schools, few faculty have received training in online instructional techniques.

It is apparent that virtually all North American dental schools have made substantial efforts to provide instructional technology resources to their faculty in the past several years, but overall use of more than twenty components and capabilities of E-curriculum by faculty is low. These results suggest that many dental schools, especially those with laptop programs, are functioning at the learning by doing phase of initial implementation in the innovation adoption model. E-curriculum planners should play close attention to the sources of stickiness (problems) at this stage because research on innovation adoption suggests that efforts to introduce a new way of doing things often collapse at this point in the process.

\section{REFERENCES}

1. Kassebaum DK, Hendricson WD, Taft T, Haden NK. The dental curriculum at North American dental institutions in 2002-03: a survey of current structure, recent innovations, and planned changes. J Dent Educ 2004;68(9): 914-31. 
2. Greenwood SR, Grigg PA, Vowles RV, Stephens CD. Clinical informatics and the dental curriculum: a review of the impact of informatics in dental care and its implications for dental education. Eur J Dent Educ 1997;1(4): 153-61.

3. Grigg P, Stephens CD. Computer-assisted learning in dentistry: a view from the UK. J Dent 1998;26(5-6):387-95.

4. Cohen PA, Forde ED. A survey of instructional technology in dental education. J Dent Educ 1992;56:123-7.

5. Eastwood KW, Louis KS. Restructuring that lasts: managing the performance dip. J School Leadership 1992; 2:212-24.

6. Bland CJ, Starnaman S, Wersal L, Moorhead-Rosenberg L, et al. Curricular change in medical schools: how to succeed. Acad Med 2000;75:575-94.

7. Levine A. Why innovations fail. Albany: State University of New York Press, 1980.

8. Lippett G, Langseth P, Mossop J. Implementing organizational change. San Francisco: Jossey-Bass, 1985.

9. Miles M, Ekholm M, Vanderberghe R, eds. Lasting school improvement: exploring the process of institutionalization. Leuven, Belgium: ACCO (Academic Publishing Co.), 1987.

10. Holloway RE. Diffusion and adoption of educational technology: a critique of research design. In: Jonassen DH, ed. Handbook of research for educational communications and technology. New York: Simon \& Schuster/ Macmillan, 1998:1107-33.

11. Bolman LG, Deal T. Reframing organizations. San Francisco: Jossey-Bass, 1991.

12. Collins JC, Porras JI. Built to last: successful habits of visionary companies. New York: Harper-Collins, 1997.

13. Duncan WJ, Ginter PM, Swayne LE. The nature of strategic management. In: Strategic management of health care organizations. $2^{\text {nd }}$ ed. Cambridge, MA: Blackwell, 1995.

14. Wentzer HS. Technology development and implementation in the public health institutions and pedagogical task for the learning organization. Stud Health Tech Informatics 2000;77:264-70.

15. Bloom SW. The medical school as a social organization: the sources of resistance to change. Med Educ 1989; 23:228-41

16. Goffee R, Jones G. What holds the modern company together? Harvard Bus Rev 1996;74(Nov.-Dec.):133-48.

17. Berquist WH. The four cultures of the academy. The Jossey-Bass Higher and Adult Education Series. San Francisco: Jossey-Bass, 1992.
18. Schein EH. Three cultures of management: the key to organizational learning. Sloan Management Rev 1996; 380:9-20

19. Ockene J, McBride P, Sallis J, Bonollo D, Ockene I. Synthesis of lessons learned from cardiopulmonary preventive interventions in healthcare practice settings. Ann Epidemiol 1997;S7:S32-6.

20. McBride P, Underbakke G, Plane MB, et al. Improving prevention systems in primary care practices: the Health Education and Research Trial. J Fam Prac 2000;49(2): 115-25.

21. Palloff RM, Pratt K. Lessons from the cyberspace classroom: the realities of online teaching. San Francisco: Jossey-Bass, 2001.

22. Rice ML, Wilson EK, Bagley W. Transforming learning with technology: lessons from the field. J Tech Teacher Educ 2001;9(2):211-30.

23. Andrews KG, Demps EL. Distance education in the U.S. and Canadian undergraduate dental curriculum. J Dent Educ 2003;67(4):427-38.

24. Argote L. Organizational learning: creating, retaining and transferring knowledge. Norwell, MA: Kluwer, 1999.

25. Ingerman BL. Form follows function: establishing the necessary infrastructure. In: Barone CA, Hagner PR, eds. Technology-enhanced teaching and learning. San Francisco: Jossey-Bass, 2001.

26. Szulanski G. The process of knowledge transfer: a diachronic analysis of success. Org Behav Human Decision Processes 2000;82(1):9-27.

27. Noer DM. Breaking free: a prescription for personal and organizational change. San Francisco: Jossey-Bass, 1997.

28. Hendricson WD, Cohen PA. Oral health care in the $21^{\text {st }}$ century: implications for dental and medical education. Acad Med 2001;77(12):1181-206.

29. Smircich L, Morgan G. Leadership: the management of meaning. J Appl Behav Sci 1982;18:257-73.

30. Tyre MJ, Orlikowski WJ. Windows of opportunity: temporal patterns of technological adaptation in organization. Org Sci 1994;5(1):98-118.

31. Pisano GP. Learning-before-doing in the development of new process technology. Res Policy 1996;25(7):1097-19.

32. Szulanski G. Exploring internal stickiness: impediments to the transfer of best practice within the firm. Strat Management J 1996;17:27-43.

33. Adler PS. Shared learning. Manage Sci 1990;36(8): 938-57.

34. Zucker LG. The role of institutionalization in cultural persistence. Am Sociol Rev 1977;42:726-43. 